\title{
The burden of disease due to tuberculosis in the state of Santa Catarina, Brazil ${ }^{*, * * *}$
}

\author{
A carga de doença por tuberculose no estado de Santa Catarina \\ Glênio César Nunes Ferrer, Rosemeri Maurici da Silva, \\ Kelian Tenfen Ferrer, Jefferson Traebert
}

\begin{abstract}
Objective: To estimate the burden of disease due to tuberculosis in the state of Santa Catarina, Brazil, in 2009. Methods: This was an epidemiological study with an ecological design. Data on tuberculosis incidence and mortality were collected from specific Brazilian National Ministry of Health databases. The burden of disease due to tuberculosis was based on the calculation of disability-adjusted life years (DALYs). The DALYs were estimated by adding the years of life lost (YLLs) and years lived with disability (YLDs). Absolute values were transformed into rates per 100,000 population. The rates were calculated by gender, age group, and health care macroregion. Results: The burden of disease due to tuberculosis was 5,644.27 DALYs (92.25 DALYs/100,000 population), YLLs and YLDs respectively accounting for $78.77 \%$ and $21.23 \%$ of that total. The highest rates were found in males in the 30-44 and 45-59 year age brackets, although that was not true in every health care macroregion. Overall, the highest estimated burden was in the Planalto Norte macroregion (179.56 DALYs/100,000 population), followed by the Nordeste macroregion (167.07 DALYs/100,000 population). Conclusions: In the majority of the health care macroregions of Santa Catarina, the burden of disease due to tuberculosis was concentrated in adult males, the level of that concentration varying among the various macroregions.
\end{abstract}

Keywords: Tuberculosis/epidemiology; Life expectancy; Cost of illness.

\section{Resumo}

Objetivo: Estimar a carga de doença por tuberculose no estado de Santa Catarina em 2009. Métodos: Estudo epidemiológico de delineamento ecológico. Dados sobre a incidência e mortalidade de tuberculose foram coletados de bancos de dados específicos do Ministério da Saúde do Brasil. A carga de doença por tuberculose baseou-se no cálculo de disability-adjusted life years (DALYs, anos de vida perdidos ajustados por incapacidade). Os DALYs foram estimados pela soma de years of life lost (YLLs, anos de vida perdidos) e years lived with disability (YLDs, anos vividos com incapacidade). Os valores absolutos foram transformados em taxas por 100 mil habitantes. As taxas foram calculadas por sexo, faixa etária e macrorregião de saúde. Resultados: A carga de doença por tuberculose foi de 5.644,27 DALYs (92,25 DALYs/100 mil habitantes), dos quais 78,77\% foram YlLs e 21,23\% foram YLDs. As maiores taxas foram encontradas no sexo masculino nas faixas etárias de 30-44 e 45-59 anos, com distribuição desigual por macrorregião de saúde. A maior carga foi estimada na macrorregião do Planalto Norte (179,56 DALYs/100 mil habitantes), seguida pela do Nordeste (167,07 DALYs/100 mil habitantes). Conclusões: A carga de doença por tuberculose concentrou-se em homens adultos, com distribuição desigual nas macrorregiões de saúde de Santa Catarina.

Descritores: Tuberculose/epidemiologia; Expectativa de vida; Efeitos psicossociais da doença.

*Study carried out at the University of Southern Santa Catarina, Tubarão, Brazil.

Correspondence to: Jefferson Traebert. Programa de Pós-Graduação em Ciências da Saúde, Universidade do Sul de Santa Catarina, Avenida José Acácio Moreira, 787, Dehon, CEP 88704-900, Tubarão, SC, Brasil.

Tel/Fax: 5548 3621-3363. E-mail: jefferson.traebert@gmail.com

Financial support: None.

Submitted: 13 May 2013. Accepted, after review: 4 October 2013.

**A versão completa em português deste artigo está disponível em www.jornaldepneumologia.com.br 


\section{Introduction}

Although tuberculosis is an ancient, wellknown infectious disease and is vulnerable to drug treatment for more than half a century, it remains one of the main global health concerns. ${ }^{(1)}$ Tuberculosis is one of the most significant causes of mortality in the developing world, especially in males in the 45-59 year age bracket, which places Mycobacterium tuberculosis as the single most important etiologic factor in terms of mortality among infectious diseases. ${ }^{(2)}$

Brazil currently ranks 19th in number of cases of tuberculosis among the 22 countries prioritized by the World Health Organization (WHO) that collectively account for $80 \%$ of the global burden of the disease. ${ }^{(3)}$ However, Brazil ranked 14th in 2004. ${ }^{(4)}$

Guimarães et al., ${ }^{(5)}$ in a recent study of a 20-year historical time series, reported a reduction in the incidence of tuberculosis of $11.4 \%$ worldwide, of 50\% in the Americas, and of $48.8 \%$ in Brazil. That same study also highlighted a decrease in the mortality rates of $40.0 \%, 70.7 \%$, and $70.8 \%$, respectively.

The tuberculosis/HIV co-infection reflects mortality trends due to tuberculosis in Brazil. ${ }^{(6)}$ The Brazilian Ministry of Health recommends strategies to actively search for new cases of tuberculosis, aiming at the early diagnosis, especially in high-risk groups, such as those who live with HIV and other immunosuppressive conditions. Individuals infected with $M$. tuberculosis have a $10 \%$ chance of developing tuberculosis in their lifetime, whereas individuals with HIV have an $8-10 \%$ chance per year. ${ }^{(2)}$

There are no studies in the state of Santa Catarina that include, in a single index, morbidity and mortality data regarding tuberculosis in order to estimate the burden of the disease. The proposed index to measure burden of disease is the disability-adjusted life years (DALYs). ${ }^{(7)}$ One DALY is equivalent to one year of healthy life lost or lived with disability due to a disease. The 2002 Burden of Disease Project in Brazil( ${ }^{(8)}$ reported the burden of disease due to tuberculosis in the country. Tuberculosis was found to be the 19th cause of early death in both sexes, and the 17th among men.

Between 1992 and 2002, in a study performed in Serbia ${ }^{(9)}$, a higher burden was observed among men than among women, with a progressive increase with advancing age. The rate found was
1.38 DALYs/100,000 population in the 55-64 year age group. In a recent publication, Murray et al. ${ }^{(10)}$ showed that tuberculosis accounted for $2.0 \%$ of all DALYs worldwide in 2010. However, when comparing data from 1990 with those from 2010, the authors reported a decrease of $19.4 \%$ in the total number of DALYs due to tuberculosis.

The objective of the present study was to estimate the burden of disease due to tuberculosis in the state of Santa Catarina, Brazil, in 2009.

\section{Methods}

This was an epidemiological study with an ecological design using data on morbidity and mortality due to tuberculosis in the nine health macroregions in the state of Santa Catarina in 2009.

The mortality data were obtained from the Brazilian Mortality Database, whereas the incidence data were obtained from the National Case Registry Database as cases of tuberculosis (International Classification of Diseases, 10th revision: from A15 to A19). For the purpose of compensating for occasional underreporting of the tuberculosis/ HIV co-infection and of tuberculosis alone, a rate of $17.7 \% \%^{(11)}$ and of $60 \%$ was respectively added to the data. ${ }^{(12)}$ These rates were added following the same parameters for the distribution of tuberculosis according to sex, age group, and health macroregions obtained from the National Case Registry Database in 2009.

The estimation of DALYs was carried out by adding the years of life lost (YLLs) and the years lived with disability (YLDs). The estimation of YLLs was based on the difference between the age at death and the life expectancy at birth. In the present study, the standardized values of 80 years of age for men and of 82.5 years of age for women ${ }^{(8)}$ were used in order to allow for comparisons of the results with international studies. A 3\% discount rate per year was applied in relation to the future years lost in order to estimate the YLLs in the present. ${ }^{(8)}$ The YLD rate was calculated as the product of the tuberculosis weight by the mean duration of the disease. Studies of burden of disease define a measurement designated disease weight, which attributes a numerical value to the time lived with a specific nonfatal ailment designated disease weight. In 2004, according to a WHO report, ${ }^{(13)}$ the attributed tuberculosis weight was 0.271 . According to the 
Global Burden of Disease Study, ${ }^{(7)}$ the median survival period after diagnosis for Latin America is 18 months for HIV-negative tuberculosis patients and 12 months for HIV-positive individuals. These values were used in order to define the duration of the disease.

In summary, the equations used in order to calculate YLLs, YLDs, and DALYs were:

YLLs (males) $=(80$ years - age at death $) \times$ $(-3 \%$ by year)

YLLs (females $)=(82.5$ years - age at death $)$ $\times(-3 \%$ by year $)$

YLDs (HIV-negative patients) $=0.271 \times 18$ months

YLDs (HIV-positive patients) $=0.271 \times 12$ months

\section{DALYs $=$ YLLs + YLDs}

The data were saved in electronic format (Microsoft Excel), and we used the Statistical Package for the Social Sciences, version 16.0 (SPSS Inc., Chicago, IL, USA) for descriptive analyses. The rates were calculated per 100,000 population, using the estimated population in July of 2009, distributed by sex and age groups, as a reference.

In the present study, anonymous secondary data from official public domain health information systems were used, and therefore there was neither risk of losses to individuals or institutions nor ethical principle violations.

\section{Results}

In 2009, 223 deaths were related to tuberculosis, and 2,138 patients were diagnosed with the disease in the state of Santa Catarina. Among the 2,138 patients, 563 were co-infected with HIV.

The total number of YlLs was 4,446.29, which generated a rate of $72.67 \mathrm{YLLs} / 100,000$ population. For males, it was 2,947.97 YLLs (66.3\%), with a rate of 96.98 YLLs/100,000 population. For females, it was 1,498.32 YlLs (33.7\%), generating a rate of 48.66 YlLs/100,000 population.

Regarding the age groups, the highest YLL rate was found in the 30-44 year age bracket (153.74 YlLs/100,000 population), followed by the 45-59 year age bracket (112.43 YLLs/100,000 population) and the 60-69 year age bracket (103.4 YLLs/100,000 population). The health macroregions with the highest rates were Nordeste, Planalto Norte and Planalto Serrano (Figure 1).

The total number of YLDs was 1,197.98, which generated a rate of 19.58 YLDs/100,000 population. For males, it was 809.49 YLDs (67.6\%), with a rate of $26.63 \mathrm{YLDs} / 100,000$ population. For females, it was 388.49 YLDs (32.4\%), generating a rate of 12.62 YLDs/100,000 population.

The highest YLD rates were encountered in the 45-59 year age bracket (30.20 YLDs/100,000 population), followed by the 30-44 year age bracket (28.71 YLDs/100,000 population) and the 15-29 year age bracket (21.03 YLDs/100,000 population). The health macroregions with the highest rates were Planalto Norte, Nordeste and Grande Florianópolis (Figure 1).

The total number of DALYs due to tuberculosis in Santa Catarina was 5,644.27, which generated a rate of 92.25 DALYs/100,000 population. The rates for males and females were, respectively, 123.62 DALYs/100,000 population (66.6\%) and 61.28 DALYs/100,000 population (33.4\%). The DALY rates according to the age groups are shown in Figure 2, whereas those by age groups and gender are shown in Figure 3.

The highest burden of disease was found in the macroregion Planalto Norte (179.56 DALYs/100,000 population), followed by Nordeste (167.07 DALYs/100,000 population), and Grande Florianópolis (133.14 DALYs/100,000 population), whereas the lowest rates were seen in Foz do Rio Itajaí(16.65 DALYs/100,000 population), Extremo Oeste (28.58 DALYs/100,000 population), and Meio Oeste (42.18 DALYs/100,000 population; Table 1 and Figure 4).

Overall, the male-to-female ratio was 2.02 in the state of Santa Catarina. The health macroregions with the highest and lowest maleto-female ratios were, respectively, Foz do Rio Itajaí (7.58) and Extremo Oeste (0.77; Table 1).

In terms of the ratio between the rates observed in the macroregions in relation to that found in the state, Planalto Norte showed the highest ratio (1.95) followed by Nordeste (1.81), whereas the lowest ratios were found in Foz do Rio Itajai (0.18) and Extremo Oeste (0.31; Table 1).

\section{Discussion}

The decrease in tuberculosis mortality rates is a global trend. The WHO reports that the absolute 

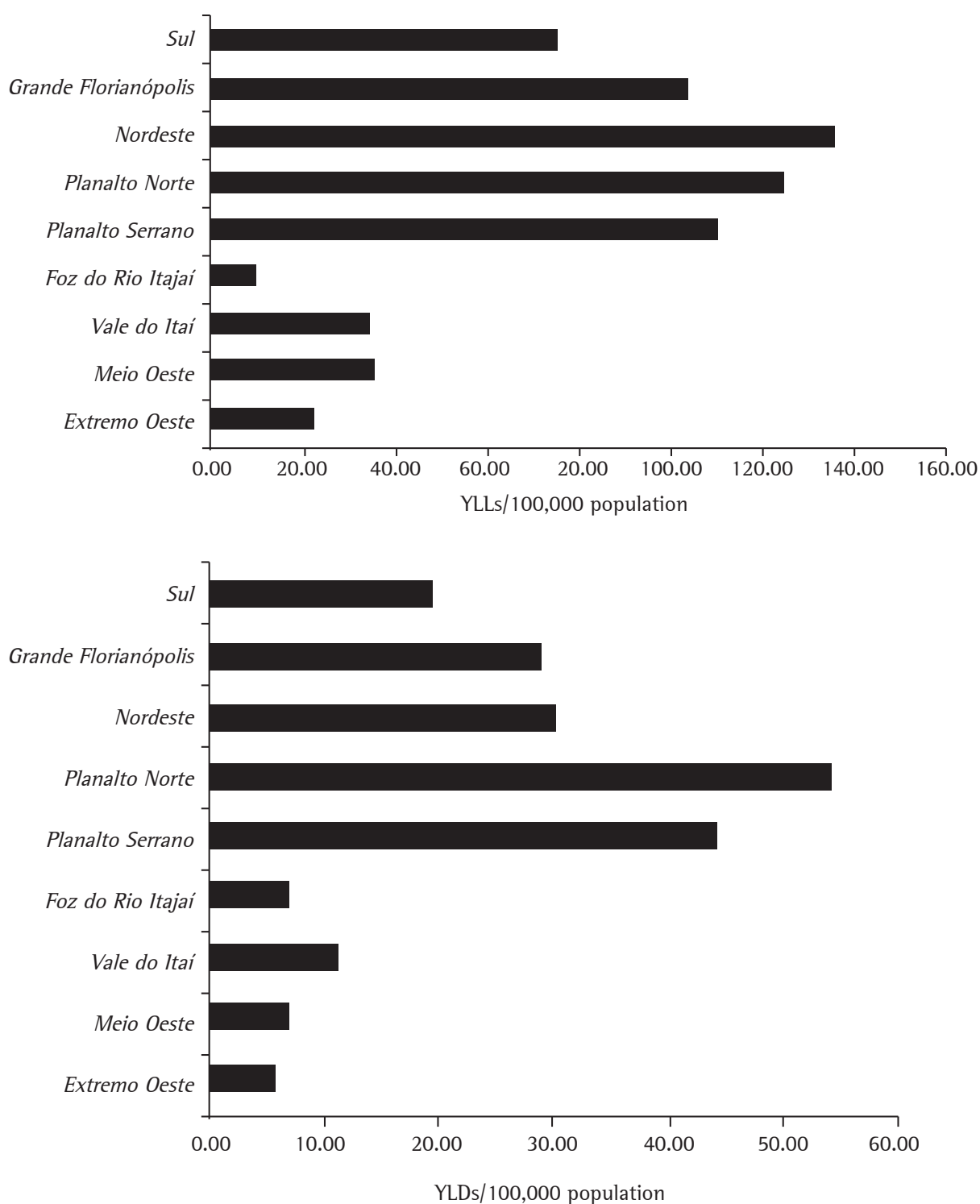

Figure 1 - Years of life lost (YLLs) and years lived with disability (YLDs) per 100,000 population according to the health macroregions in the state of Santa Catarina, Brazil, 2009.

number of cases has been falling since 2006, as has its incidence since 2002 . Mortality fell by $8.6 \%$ per annum between 1990 and 2010. ${ }^{(14)}$ This trend is also observed in various studies in Brazil. ${ }^{(15-17)}$

One aspect that might have positively influenced the mortality and incidence rates since 1999 was the implementation of the directly observed treatment, short-course (DOTS) in Brazil, which resulted in a $32 \%$ drop in mortality by 2007. ${ }^{(2,3)}$ This strategy increases cure rates by $1 \%$ a year and drastically reduces noncompliance with the treatment, which is directly related to poor disease outcomes. ${ }^{(18)}$ However, since the present study had an ecological design, the proportion of individuals in which the DOTS strategy was applied was unavailable. Nevertheless, with the implementation of this strategy as a government policy, being an integral part of the Brazilian National Tuberculosis Control Program, it could be inferred that the great majority of individuals have been offered DOTS. The decrease in morbidity and mortality could also be attributed to the free and universal access to treatment, as well as to improvements in primary health care. ${ }^{(3,14)}$ 


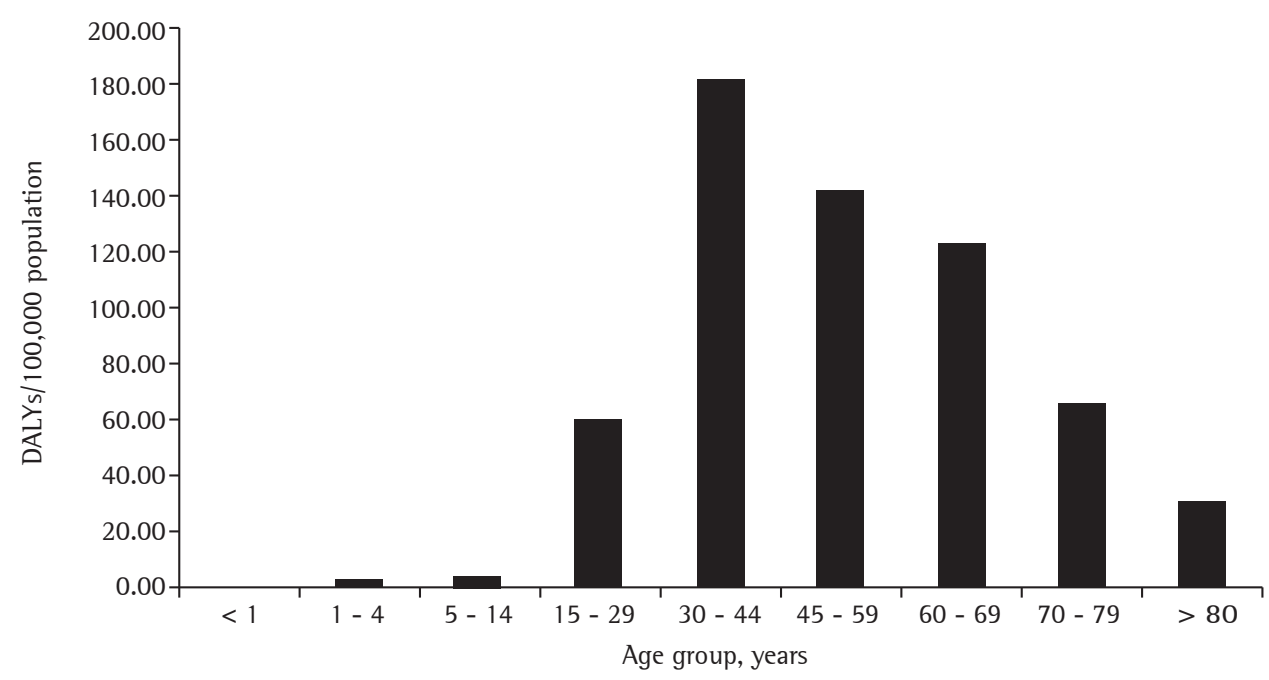

Figure 2 - Disability-adjusted life years (DALYs)/100,000 population rates according to age groups in the state of Santa Catarina, Brazil, 2009.

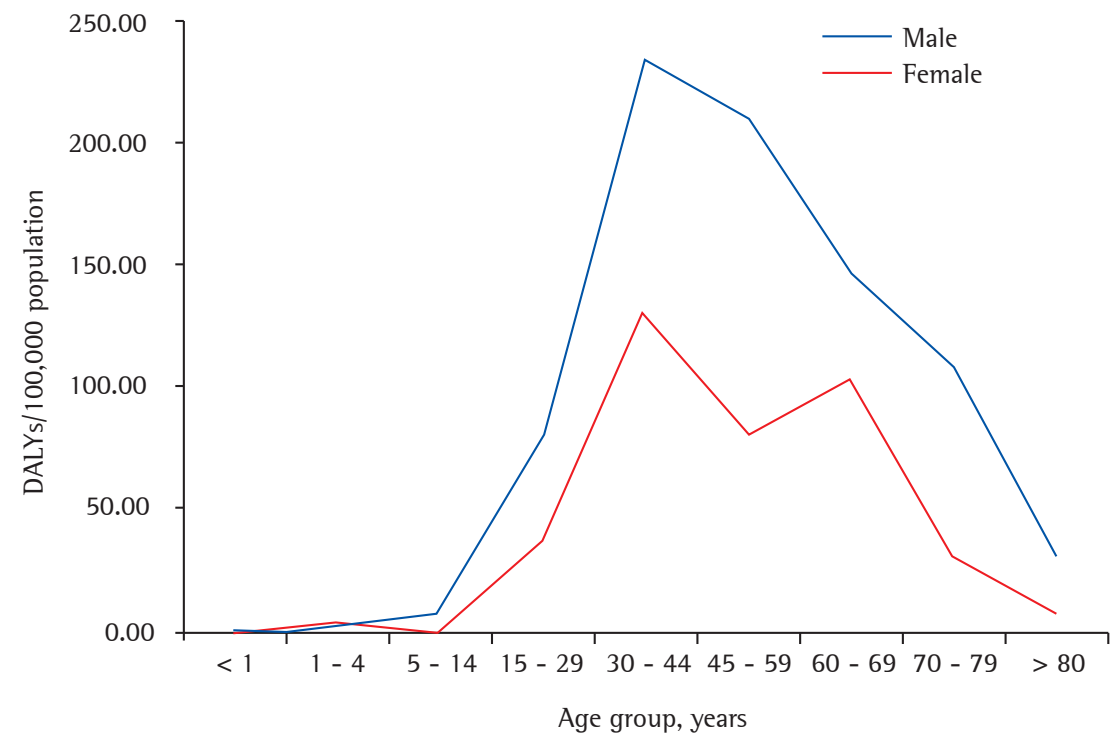

Figure 3 - Disability-adjusted life years (DALYs)/100,000 population rates according to sex and age groups in the state of Santa Catarina, Brazil, 2009.

As previously mentioned, the epidemiology of tuberculosis has been tirelessly investigated, using different methodologies, in order to provide a clearer understanding of its behavior in the country. The present study, however, sheds new light on the matter, since no previous studies have reported both morbidity and mortality by tuberculosis in the same index.

The 2002 Disease Burden Project in Brazil ${ }^{(8)}$ revealed that tuberculosis ranked 19th among the major causes of premature deaths, which translated into $1.1 \%$ of the total number of deaths in the country. However, that study did not present YLL, YLD and DALY values specifically related to tuberculosis, which prevents any comparisons with the current study.

As expected, the burden of disease due to tuberculosis in Santa Catarina was higher in males. Classic epidemiological indices had already suggested that reality. ${ }^{(2,19-21)} \ln$ the present study, the burden rate was estimated to be twice as high among males. A similar scenario was observed in a study carried out in Serbia. ${ }^{(9)}$ According to the authors, those rates for men and women were, 
Table 1 - Disability-adjusted life years/100,000 population rates by health macroregions in the state of Santa Catarina, Brazil, 2009.

\begin{tabular}{|c|c|c|c|c|c|c|c|c|c|}
\hline \multirow[t]{3}{*}{ Macroregion } & \multirow{3}{*}{$\begin{array}{c}\text { DALYs/100,000 } \\
\text { population }\end{array}$} & \multirow{3}{*}{$\begin{array}{l}\text { YLLs, } \\
\%\end{array}$} & \multirow{3}{*}{$\begin{array}{l}\text { YLDs, } \\
\%\end{array}$} & \multirow{3}{*}{$\begin{array}{c}\text { MS } \\
\text { ratio }\end{array}$} & \multirow{3}{*}{$\begin{array}{l}\text { MF } \\
\text { ratio }\end{array}$} & \multicolumn{4}{|c|}{ Most affected age brackets } \\
\hline & & & & & & \multicolumn{2}{|c|}{ Males } & \multicolumn{2}{|c|}{ Females } \\
\hline & & & & & & $1 \mathrm{st}$ & 2nd & $1 \mathrm{st}$ & 2nd \\
\hline Extremo Oeste & 28.58 & 78.61 & 21.39 & 0.31 & 0.77 & $70-79$ & $30-44$ & $30-44$ & $15-29$ \\
\hline Meio Oeste & 42.18 & 84.96 & 15.04 & 0.46 & 2.51 & $45-59$ & $30-44$ & $70-79$ & $30-44$ \\
\hline Vale do Itajaí & 45.99 & 75.92 & 24.08 & 0.50 & 4.63 & $30-44$ & $70-79$ & $45-59$ & $15-29$ \\
\hline Foz do Rio Itajaí & 16.65 & 60.78 & 39.22 & 0.18 & 7.58 & $30-44$ & $15-29$ & $60-69$ & $45-59$ \\
\hline Planalto Serrano & 126.30 & 87.52 & 12.48 & 1.37 & 1.94 & $60-69$ & $15-29$ & $60-69$ & $30-44$ \\
\hline Planalto Norte & 179.56 & 69.70 & 30.30 & 1.95 & 1.09 & $45-59$ & $15-29$ & $30-44$ & $15-29$ \\
\hline Nordeste & 167.07 & 81.58 & 18.42 & 1.81 & 2.02 & $45-59$ & $60-69$ & $60-69$ & $30-44$ \\
\hline Grande Florianópolis & 133.14 & 78.13 & 21.87 & 1.44 & 2.20 & $30-44$ & $45-59$ & $60-69$ & $45-59$ \\
\hline Sul & 94.94 & 79.59 & 20.41 & 1.03 & 2.41 & $30-44$ & $60-69$ & $45-59$ & $30-44$ \\
\hline Santa Catarina state & 92.25 & 78.78 & 21.22 & - & 2.02 & $30-44$ & $45-59$ & $30-44$ & $60-69$ \\
\hline
\end{tabular}

DALYs: disability-adjusted life years; YLLs: years of life lost; YLDs: years lived with disability; MS: macroregion to state; and MF: male to female.

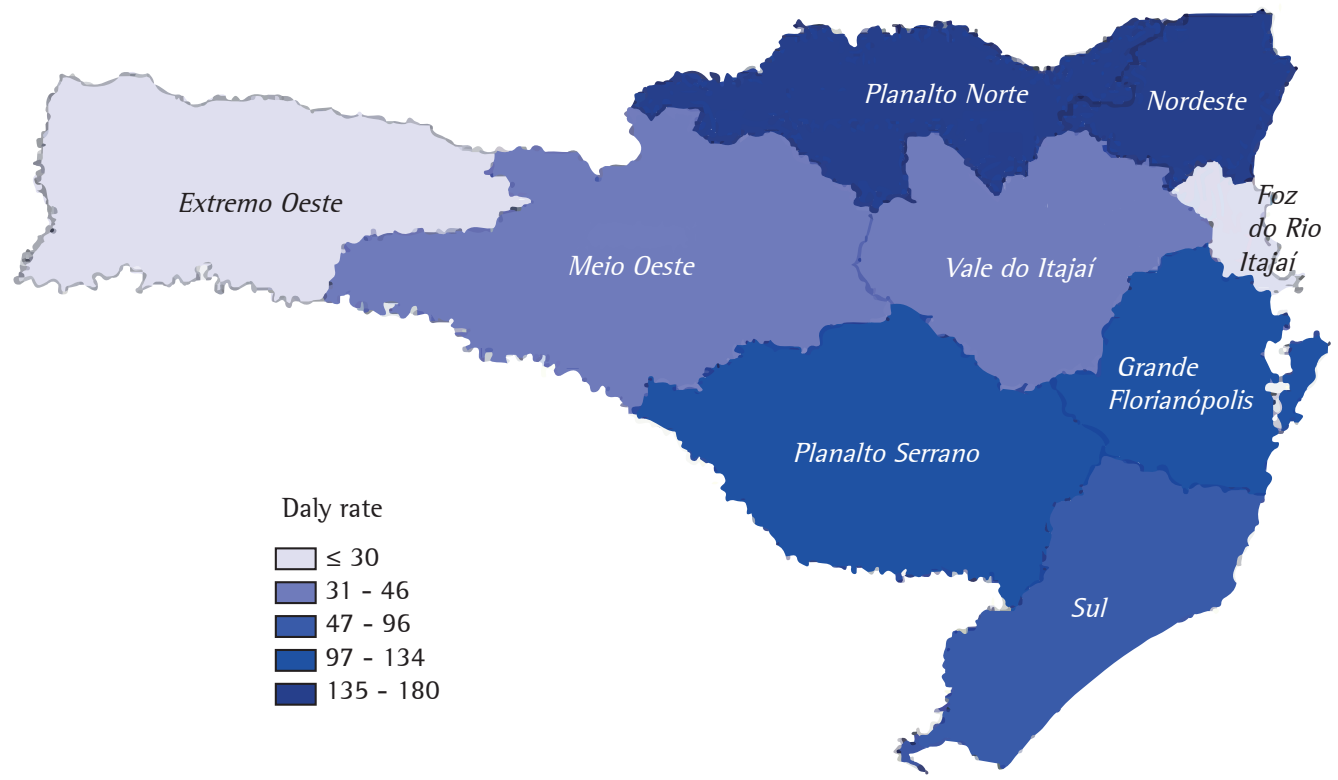

Figure 4 - Disability-adjusted life years (DALYs)/100,000 population rates according to the health macroregions in the state of Santa Catarina, Brazil, 2009.

respectively, 36.7 DALYs/100,000 population and 21.4 DALYs/100,000 population.

The YLL rate was found to be considerably high due to the fact that mortality by tuberculosis is associated with HIV infection, which is highly prevalent in the state of Santa Catarina. Even with antiretroviral therapy, individuals living with HIV have a high incidence of tuberculosis, showing low AFB counts in sputum and a high incidence of multidrug-resistant tuberculosis. ${ }^{(2)}$

The 30-44 year age bracket was the age group most affected for both sexes, whereas the 45-59 and the 60-69 year age brackets were more prevalent for males and females, respectively. Similar age brackets have also been reported in other studies. In developing countries, $80 \%$ of 
the infected individuals are between 15 and 59 years of age-mostly men in the economically active age group-causing a negative impact on economic growth and, consequently, on social development, generating more poverty and social exclusion. ${ }^{(22)}$

The distribution of the burden of disease has unearthed heterogeneous realities throughout the health macroregions of the state. Planalto Norte, Nordeste, Grande Florianopolis, and Planalto Serrano showed rates higher than 100 DALYs/100,000 population, whereas Extremo Oeste and Foz do Rio Itajaí had rates lower than 30 DALYs/100,000 population. The heterogeneous distribution could be explained by the analysis of various aspects, including the quality of the health care facilities in each macroregion. The gap between the demand for medical services and the diagnosis, with the consequent notification of tuberculosis cases, might have contributed to the increased morbidity and mortality rates.

One should take into consideration the likely underreporting of tuberculosis cases when measuring the burden of disease. Another possible limitation of the present study was the use of parameters defined by the WHO that reflected the tuberculosis trends in Latin America in the 2000s. Such parameters might have had a limiting impact on the estimation of the current burden, despite being the best available parameters to date, permitting comparisons between both national and international studies.

In conclusion, despite the need for a degree of caution when interpreting the present results, the use of DALYs is recommended as a helpful tool to assess priorities in terms of specific profiles regarding tuberculosis in the state of Santa Catarina. Further studies regarding the burden of disease due to tuberculosis are necessary in order to generate parameters for comparisons in the state and in Brazil as a whole, as well as to identify impact trends.

\section{References}

1. Barreira D, Grangeiro A. Evaluation of tuberculosis control strategies in Brazil. Foreword [Article in Portuguese]. Rev Saude Publica. 2007;41 Suppl 1:4-8. http://dx.doi. org/10.1590/S0034-89102007000800002 PMid:18038085

2. Conde MB, Melo FA, Marques AM, Cardoso NC, Pinheiro VG, Dalcin Pde T, et al. 111 Brazilian Thoracic Association Guidelines on tuberculosis. J Bras Pneumol. 2009;35(10):1018-48. PMid:19918635

3. Brasil. Ministério da Saúde. Secretaria de Vigilância em Saúde. Departamento de Vigilância Epidemiológica.
Manual de recomendações para o controle da tuberculose no Brasil. Brasília: Ministério da Saúde; 2011.

4. World Health Organization. Global Tuberculosis Control WHO Report 2010. Geneva: World Health Organization; 2010.

5. Guimarães RM, Lobo Ade P, Siqueira EA, Borges TF, Melo SC. Tuberculosis, HIV, and poverty: temporal trends in Brazil, the Americas, and worldwide. J Bras Pneumol. 2012;38(4):511-7. http://dx.doi.org/10.1590/S180637132012000400014 PMid:22964936

6. Bierrenbach AL, Stevens AP, Gomes AB, Noronha EF, Glatt $\mathrm{R}$, Carvalho $\mathrm{CN}$, et al. Impact on tuberculosis incidence rates of removal of repeat notification records [Article in Portuguese]. Rev Saude Publica. 2007;41 Suppl 1:67-76. http://dx.doi.org/10.1590/S0034-89102007000800010 PMid:18038093

7. Murray CJ, Lopez AD. Estimating causes of death: new methods and global and regional applications for 1990. In: Murray CJ, Lopez AD, editors. The Global Burden of Disease: a comprehensive assessment of mortality and disability from diseases, injuries, and risk factors in 1990 and projected to 2020. Boston: Harvard School of Public Health; 1996. p. 117-200.

8. Escola Nacional de Saúde Pública. Fundação Oswaldo Cruz. Projeto Carga de Doença: relatório final do projeto estimativa da carga de doença do Brasil - 1998. Rio de Janeiro: FlOCRUZ; 2002.

9. Gledovic Z, Vlajinac H, Pekmezovic T, Grujicic-Sipetic S, Grgurevic A, Pesut D. Burden of tuberculosis in Serbia. Am J Infect Control. 2006;34(10):676-9. http://dx.doi. org/10.1016/j.ajic.2006.03.013 PMid:17161745

10. Murray CJ, Vos T, Lozano R, Naghavi M, Flaxman AD, Michaud C, et al. Disability-adjusted life years (DALYs) for 291 diseases and injuries in 21 regions, 1990-2010: a systematic analysis for the Global Burden of Disease Study 2010. Lancet. 2012;380(9859):2197-223. http:// dx.doi.org/10.1016/S0140-6736(12)61689-4

11. Carvalho CN, Dourado 1, Bierrenbach AL. Underreporting of the tuberculosis and AIDS comorbidity: an application of the linkage method. Rev Saude Publica. 2011;45(3):548-55. http://dx.doi.org/10.1590/S0034-89102011005000021 PMid:21503555

12. Galesi VM. Mortalidade por Tuberculose no Município de São Paulo: análise de uma década, 1986 a 1995 [dissertation]. São Paulo: Universidade de São Paulo; 1999.

13. World Health Organization. Global Burden of Disease 2004 update: disability weights for diseases and conditions. Geneva: WHO; 2004.

14. World Health Organization. Global Tuberculosis Control: WHO report 2011. Geneva: WHO; 2011.

15. Bierrenbach AL, Duarte EC, Gomes AB, Souza Mde F. Mortality trends due to tuberculosis in Brazil, 1980-2004 [Article in Portuguese]. Rev Saude Publica. 2007;41 Suppl 1:15-23. http://dx.doi.org/10.1590/S003489102007000800004 PMid:18038087

16. Hino $\mathrm{P}$, da Costa-Júnior ML, Sassaki CM, Oliveira MF, Villa TC, dos Santos CB. Time series of tuberculosis mortality in Brazil (1980-2001). Rev Lat Am Enfermagem. 2007;15(5):936-41. http://dx.doi.org/10.1590/S010411692007000500009 PMid:18157445

17. Traebert J, Ferrer GC, Nazário NO, Schneider 1J, Silva RM. Temporal trends in tuberculosis-related morbidity and mortality in the state of Santa Catarina, Brazil, between 2002 and 2009. J Bras Pneumol. 2012;38(6):771-5. 
http://dx.doi.org/10.1590/S1806-37132012000600014 PMid:23288124

18. Domingos MP, Caiaffa WT, Colosimo EA. Mortality, TB/ HIV co-infection, and treatment dropout: predictors of tuberculosis prognosis in Recife, Pernambuco State, Brazil. Cad Saude Publica. 2008;24(4):887-96. http://dx.doi. org/10.1590/S0102-311X2008000400020 PMid:18392367

19. Cortezi MD, Silva MV. Abandono do tratamento da tuberculose em pacientes co-infectados com HIV em Itajaí, Santa Catarina, 1999 - 2004 Bol Pneumol Sanit. 2006;14(3):145-52.
20. Silveira MP, de Adorno RF, Fontana T. Profile of patients with tuberculosis: evaluation of the Brazilian national tuberculosis control program in Bagé, Brazil. J Bras Pneumol. 2007;33(2):199-205. http://dx.doi.org/10.1590/ S1806-37132007000200015 PMid:17724540

21. Coelho AG, Zamarioli LA, Perandones CA, Cuntiere 1, Waldman EA. Characteristics of pulmonary tuberculosis in a hyperendemic area: the city of Santos, Brasil. J Bras Pneumol. 2009;35(10):998-1007. PMid:19918633

22. Chirinos NEC, Meirelles BHS. Fatores associados ao abandono do tratamento da tuberculose: Uma revisão integrativa. Texto Contexto- Enferm. 2011;20(3):599-406.

\section{About the authors}

\section{Glênio César Nunes Ferrer}

Master's Student. Graduate Program in Health Sciences, University of Southern Santa Catarina, Tubarão, Brazil.

Rosemeri Maurici da Silva

Professor. Graduate Program in Health Sciences, University of Southern Santa Catarina, Tubarão, Brazil.

\section{Kelian Tenfen Ferrer}

Nurse, Santa Rosa de Lima City Hall, Santa Rosa de Lima, Brazil.

\section{Jefferson Traebert}

Professor. Graduate Program in Health Sciences, University of Southern Santa Catarina, Tubarão, Brazil. 